\title{
AVALIAÇÃO DA QUALIDADE DO SERVIÇO DE LOGÍSTICA: UM ESTUDO DE CASO EMPÍRICO DO SETOR FARMACÊUTICO
}

\section{Logistic service quality evaluation: an empirical case study from the pharmaceutical sector}

Envio 25.06.08 / Aceite 20.07.08

\author{
José Ignácio Villela Júnior ${ }^{1}$ \\ Gustavo Quiroga Souki² \\ Cid Gonçalves Filho ${ }^{3}$
}

\begin{abstract}
The opening of markets caused a great change in customer-supplier relationships. Regarding to this new context, it is up to companies to implement strategies that consider this new reality and differentiate them from their competitors. In a view of the fact that it is necessary to attend to customer expectations at a cost which guarantees minimum profitability to a company, customer service management becomes an important variable in guaranteeing a company's competitive advantage. In this situation, the issue, which is the object of this research, arises at this point: how to evaluate the logistic services quality provided by a pharmaceutical companies from the point of view of its retail customers? This research has been developed through a survey measuring a reliable scale of Logistics Service Quality in a pharmaceutical industry.
\end{abstract}

Keywords: Logistics; Service Level; Logistics Service Quality; Pharmaceutical Industry.

\footnotetext{
${ }^{1}$ Mestre Profissional em Administração. Universidade Estácio de Sá. Endereço: Rua Sevilha, 250. CEP 34000-000 Nova Lima, MG - Brasil. Telefone: (31)3581-7196. E-mail: jose.ignacio@uol.com.br

${ }^{2}$ Doutor em Administração. Universidade Fumec. Endereço: Rua Sevilha, 250. CEP 34000-000 - Nova Lima, MG Brasil. Telefone: (31)3581-7196. E-mail: souki@consumer.com.br

${ }^{3}$ Doutor em Administração. Fundação Mineira de Educação e Cultura (FUMEC). Endereço: Av Afonso Pena, 3880. Bairro Cruzeiro. CEP 30130009 - Belo Horizonte, MG - Brasil. Telefone: (31) 32283060 Fax: (31) 32283060. E-mail: cid@facefumec.br
} 


\section{Introduction}

The opening of markets caused a great change in customer-supplier relationships, such as customers began to demand more from the supplier and the price factor ceased to be the only determining factor in the purchasing process. Research carried out by CEL (2003) confirms this new situation. According to data from this research, the price factor is still the most important variable in retail purchasing decisions but the significance of other variables such as product and customer service have been growing in importance as regards purchasing decisions for consumer goods.

According to Fleury (2000), the quickly advances in telecommunications, transport, data processing, technology dissemination (transforming some products into commodities) have increased the range of choices available to customers, to the point that questions such as after-sales service, overall service, flexibility, reliability, etc., have come to determine purchasing decisions.

Regarding to this new context, it is up to companies to implement marketing strategies that take this new reality into consideration and differentiate them from their competitors. According to Bowersox and Closs (2001, p. 307) 'in order to implement a marketing strategy, it is essential survey and become familiar with all the activities related to the process of winning over customers and attending to their needs. Logistics is one of the key competencies that has to be developed as a central part of such a strategy'. According to these authors it is also the case that creating a competitive advantage based on logistic competence allows companies to create a difference in relation to other companies in the market, making it difficult for competitors to copy it. However, if there is no such thing as a static competitive environment, it is up to companies to take a dynamic approach to the analysis of their logistic performance and to take into account the fact that customer needs continually changing. According to Dantas (2000), in this context, logistics is an essential tool for increasing flexibility, improving service and reducing costs, all of them are indispensable factors for any company that wish to compete in the present scenario.

According to Fawcett (1996), it is possible to obtain differentiated results for customer satisfaction as well as cost reductions by means of logistics process management. For this author, logistics is an important option, not only because it increases operational efficiency but also because it can lead to a steady increase in customer loyalty. Daugherty, Sabath and Rogers (1992) complements this point when he mentions that it is important to be able to personalize customer service and react quickly to customer requirements. However, this will only be converted into competitive advantage if profit margins and profitability will not be sacrificed. Attending to customer expectations in an indiscriminate manner is not necessarily advantageous, especially if costs are not taken into account.

In view of the fact that it is necessary to attend to customer expectations at a cost which guarantees minimum profitability to a company, customer service management becomes an important variable in guaranteeing a company's competitive advantage. If the customer expects to receive the elements of service are correctly identified, a company can focus its efforts on trying to satisfy them and avoid expenditure on elements that add no value. In this situation and at this point that the issue which is the object of this research arises: how to evaluate the quality of logistic services provided by a pharmaceutical company from the point of view of its retail customers. 


\section{Integrated logistics}

In 1991, the Council of Logistics Management (CLM) modified its distribution management definition, which had been in force for 15 years, and adopted a wider definition of Logistics, as follows:

Logistics is the efficient and effective process of planning, implementation and control of the flow and storage of goods, services and information from their point of origin to their point of consumption, with the aim of meeting customer needs.

Bowersox and Closs (2001) emphasize two important characteristics of Logistics which are contained in this definition from the CLM:

- the integration of such functions as buying, production planning and physical distribution, backed up by materials and information flow;

- the marketing concept application in combination with the logistics concept in such a way that all of the company's efforts should be directed into attending to customer needs.

As part of the marketing effort, logistics plays a key role in customer satisfaction and in the company's overall profitability. The efficient management of logistics complements the company's marketing efforts and provides effective goods supply to the customer by putting its products in the right place and at the right time. In this way, it deals with two of the attributes which, from the customer's point of view, give value to a product or service. The ability of logistics to provide the customer with service along with the ability of marketing to generate and complete the sales cycle should create an acceptable level of customer satisfaction leading to a differential market. In general, it can be mentioned that logistics should concentrate on supplying the customer with the right product in the right place, at the right moment, in the right conditions and at the right cost. This logistics optimization should occur at the same time as the right level of service to the customer is reached. In general it can be mentioned that the objective of marketing is to allocate resources to the marketing mix (or the $4 \mathrm{P}^{\prime} \mathrm{s}$ ) in order to maximize company profits in a long term, while the objective of logistics is to minimize overall costs, in relation to the objective of customer service, where overall cost is the sum of the costs originating from transport, warehousing, information, production of batches of goods and inventory (LAMBERT, 1998).

Ballou (2001) and Christopher (1997) state that one of the most important commercial tendency of the $20^{\text {th }}$ century was the emergence of logistics as an integrating concept covering the whole of the supply chain from raw materials to the point of sale. The fundamental philosophy underlying this concept is one of planning and coordination of the materials flow from source to user as an integrated system instead of, as is only too common, managing the goods flow as a series of independent activities. In this way, in a logistics management system, the object is to link the market, the distribution network, the manufacturing process and the activity of acquiring the product, in such a way to provide the customers with increasingly higher levels of service, while keeping costs down.

\section{Customer service}

In what has been presented so far, the authors cited agree on the fact that one of the key points in an organization's success has to be Customer Satisfaction, and, this being the case, it is objectively necessary to define what it means to Satisfy the Customer, that is, what should be the standard of service offered, or, even, what the customers' demands and needs.

Rev. Adm. UFSM, Santa Maria, v. 1, n. 2, p. 209-224, mai./ago. 2008 
For LaLonde (apud BOWERSOX and CLOSS, 2001, p.71), 'Customer Service is a process whose objective is to supply significant aggregate value benefits to the supply chain in a cost efficient manner'. Bowersox and Closs (2001) add that a service that is offered beyond the basic level is normally defined as an added value service. Such services should be directed towards specific customers as an extension of the basic service offered by the company, since they involve extra costs and these costs should be 'paid for' by the customers who receive them.

According to Lambert (1998), the level of service is the best way to translate this emphasis on satisfying the customers' expectations. Logistic services are a management function of a number of the system's operational variables, such as orders and transport processing and warehousing. All these factors, in addition to pricing decisions, advertising and product define the organization's marketing mix. Sharma, Grewal and Levy (1995) state that high levels of service create a sustainable competitive advantage, given that the improvements made in the company's distribution services cannot be as easily replicated as improvements in the other components of the marketing mix.

Ballou (2001), Bowersox and Closs (2001) and Christopher (1997) highlight the fact that the customer service purpose is to provide 'time and place utility' in goods transfer between the buyer and the seller. According to these authors, the value of a particular product only becomes real from the moment when it is available 'in the customer's hands'. Rosenbloom (2002) adds that making the product 'available' is, essentially, all that is asked of the distribution function in the business. According to Bowersox and Closs (2001), Christopher (1999) and Lambert (1998), the key to succeed in achieving a profitable and lasting relationship with the customer lays in good performance in the main contact areas between the organization and the customer, that is, Marketing and Logistics. This being the case, the way to succeed begins with the integration of these functions. In this context, Customer Service is a wide-ranging concept that takes in tangible and intangible elements of the customer-supplier relationship, and where the Logistics performance is fundamental in order to achieve customer satisfaction.

According to Christopher (1997), it is important to bear in mind that service needs of either two customers will never be exactly the same. However, it frequently happens that various customers form groups or 'segments' that are characterized by a broad similarity in this area. These groupings can be seen as 'service standards'. The segmentation of services approach which is suggested here is a three-stage process:

1) Identification of the customer service key components from the point of view of the actual customers;

2) Establishment of the relative importance that customers attribute to these service components;

3) Identification of customers 'groups' according to the similarity of their service preferences.

\section{Elements of customer service}

Over the years, researchers and professionals in logistics concentrated their attention on the elements of customer service provided by the logistic system. Various attempts were made to define and list these elements and also to measure the performance in terms of what was conventionally called service standards. According to Bowersox and Closs (2001), the service supplied performance research and evaluation are consistent with the following fundamental ideas on which marketing is based: 
- customer needs come before goods and services;

- goods and services only have value when they are available and located in accordance with the customer's criteria;

- profitability is more important than sales volume.

These same authors also state that customer service has three basic dimensions that must be satisfied. They are:

- availability, the capacity to maintain available stocks at the location and in quantities (percentage availability) requested by the customer;

- performance, excellence in operational performance in terms of rapidity, consistency, flexibility, and recovery from errors;

- reliability (a synonym for logistic quality), the capacity to comply with established standards regarding availability and performance.

In view of the large variety of components making up the concept of customer service, Bowersox and Closs (2001) and Christopher (1997) make the point that it is important to understand that some of these components are more relevant than others and, as a result, it is essential to understand customer service in terms of requirements that reflect the different segments of the market and not as an universally applicable list. Ballou (2001) complements this point when he states that a different degree of importance should be attributed to each different element in each of the markets in which a company competes. In addition to this, according to Bowersox and Closs (2001), any additional service beyond the basic level should be directed towards specific customers because such services have a cost and should be 'paid for' by the customers who receive them.

According to Christopher (1997), the main aim of any customer service strategy should be to increase customer retention, although this does not mean that the strategy should not play an important role in winning over new customers. In this context, Christopher (1997) and Kotler (2000) state that a new marketing and logistics emphasis have quickly emerged. It is directed at the development of customer 'relationships' where such a high level of satisfaction is achieved that customers do not even feel the need to consider offers from alternative suppliers. Gustafsson (2003) puts forward the idea those offering customers a precision-made logistic service is an enormous source of competitive advantage and that the objectives of logistic service should be planned at the strategic level. According to this author, logistic service has three dimensions. The first and most basic of these is functionality or the activity level. The second dimension is related to performance and quantifies the level of service specified. The third and last dimension has to do with philosophy (company) and puts emphasis on the approach to customer service adopted by the company as a whole.

\section{Research into evaluation of service levels}

Given the importance of the level of service for a company's performance, literature presents a large number of research pieces on this topic. They range from the purely theoretical to the development of scales for measuring the service level provided. Among the research pieces which seek to measure service levels, some stand out and are presented immediately below (Table 1). 
Table 1 - Elements of Customer Service according to a Selection of Authors

\begin{tabular}{|c|c|c|c|c|c|c|c|c|c|c|c|c|}
\hline & A & & & $\mathrm{E}$ & & $\mathrm{H}$ & I $\mid$ & & $\mathrm{L}$ & & $\mathbf{N}$ & $\begin{array}{l}\text { No. of } \\
\text { Citations }\end{array}$ \\
\hline Average Delivery Time & $x$ & $\mathrm{x} \mid \gamma$ & $x \mid x$ & $x$ & $x \mid x$ & $x$ & $x \mid x$ & $x$ & $x$ & $x$ & & 13 \\
\hline Accuracy in Dealing with the Order & $x$ & $x>$ & $x \mid x$ & & $x \mid x$ & $x$ & \begin{tabular}{|l|l|l}
$x$ & $x$ \\
\end{tabular} & & $\mathrm{x}$ & $x$ & & 11 \\
\hline Availability & & $\mathrm{x} \times \mathrm{\gamma}$ & \begin{tabular}{l|l}
$x$ \\
\end{tabular} & $x$ & \begin{tabular}{l|l|}
$x$ \\
\end{tabular} & $\mathrm{x}$ & $x$ & & $\mathrm{x}$ & & $\mathrm{x}$ & 10 \\
\hline $\begin{array}{l}\text { Variability and Consistency of Delivery } \\
\text { Dates }\end{array}$ & $x$ & $x \mid>$ & $x$ & $x$ & $x \mid x$ & & $x \mid x$ & & & $\mathrm{x}$ & & 9 \\
\hline Emergency and Special Service & $x$ & $\mathrm{x} x$ & $x$ & & $x$ & $x$ & & & $\mathrm{x}$ & $\mathrm{x}$ & & 7 \\
\hline Lack of Damage & & & $x$ & & $x$ & $x$ & $\mathrm{x}$ & $x$ & $\mathrm{x}$ & $\mathrm{x}$ & & 7 \\
\hline $\begin{array}{l}\text { Consistency in Fulfillment of Delivery } \\
\text { Dates }\end{array}$ & & & & & $x$ & & $x \mid x$ & & $\mathrm{x}$ & $x \mid x$ & $x$ & 6 \\
\hline Late Deliveries & & $x$ & & & $x$ & $x$ & & $x$ & $x$ & $x$ & & 6 \\
\hline Methods of Issuing Orders (speed) & $x$ & & & $x$ & & $x$ & $x$ & $x$ & $x$ & & & 6 \\
\hline Handling of Complaints & $\mathrm{x}$ & $\gamma$ & $x$ & & $\mathrm{x}$ & $\mathrm{x}$ & & $\mathrm{x}$ & & & & 5 \\
\hline $\begin{array}{l}\text { Trustworthiness of Information given by } \\
\text { the Sales Team }\end{array}$ & & & & & $x$ & $x$ & & $x$ & & $x \mid x$ & $x$ & 5 \\
\hline Percentage of the Total Order Delivered & & & & & & $x$ & $x$ & & $x$ & $\mathrm{x}$ & & 4 \\
\hline Information on Order Status & $x$ & $x$ & $x$ & & & $x$ & $x$ & & & & & 4 \\
\hline Flexibility & & $>$ & $x$ & & $x$ & $x$ & & & & & & 4 \\
\hline $\begin{array}{l}\text { Information on Availibity of Stock } \\
\text { at Time of Placement of Order. }\end{array}$ & & & & & $x$ & & & & $x$ & & $x$ & 3 \\
\hline $\begin{array}{l}\text { Percentage of Demand Satisfied on Issue } \\
\text { of Order }\end{array}$ & & & & & & $x$ & $x$ & & & & $x$ & 3 \\
\hline Time taken to Correct Errors & & & & & & $x$ & $x$ & & & $x$ & & 3 \\
\hline $\begin{array}{l}\text { Percentage of Deliveries with Unresolved } \\
\text { Issues }\end{array}$ & & & & & & $x$ & $x$ & & $x$ & & & 3 \\
\hline Reliability of Transport Companies & & & & & $x$ & $\mathrm{x}$ & & $x$ & & & & 3 \\
\hline Efficient Communication & & & & $x$ & & & & & $\mathrm{x}$ & $x$ & & 3 \\
\hline Availability of Technical Information & & & & & & & & $x$ & $x$ & $x$ & & 3 \\
\hline Policy on Returns & $x$ & & & $x$ & $x$ & & & & & & & 3 \\
\hline Conformity of Product to Specification & & & & & $\mathrm{x}$ & & & $x$ & & & $x$ & 3 \\
\hline Competence of Sales Team & & & & & $x$ & $x$ & & $x$ & & & & 3 \\
\hline Technical Knowledge of Sales Team & & & & & $\mathrm{x}$ & $\mathrm{x}$ & & $x$ & & & & 3 \\
\hline Delivery of Correct Product & & & & & $\mathrm{x}$ & & $x$ & & & $x$ & & 3 \\
\hline Response Time for such Requests & & & & & & $\mathrm{x}$ & $x$ & & $\mathrm{x}$ & & & 3 \\
\hline Accessibility & & $x$ & $x \mid x$ & & & & & & $x$ & & & 3 \\
\hline Minimum Quantity and Variety & & & $\mathrm{x}$ & & & & & $x$ & $x$ & & & 3 \\
\hline Low Number of Product Defects & & & & & $x$ & & & $x$ & & & & 2 \\
\hline Prior Notice of Delays & & $\mathrm{x}$ & & & $\mathrm{x}$ & & & & & & & 2 \\
\hline $\begin{array}{l}\text { Time taken for Delivery of Goods \& } \\
\text { Services } \\
\text { with Unresolved Issues }\end{array}$ & & & & & & $x$ & & $x$ & & & & 2 \\
\hline Control of Delivery Operations & & & & & $x$ & $|x|$ & & & & & & 2 \\
\hline
\end{tabular}


(cont. Table 1)

\begin{tabular}{|c|c|c|c|c|c|c|c|c|c|c|}
\hline & & $\mathrm{C}$ & & $\mathrm{F}$ G & $\mathrm{H}$ & I J & $K \mathbf{L}$ & $M$ & $\mathbf{N}$ & $\begin{array}{l}\text { No. of } \\
\text { Citations }\end{array}$ \\
\hline Normal Delivery Situations & & & & & $\mathrm{x}$ & & & $x$ & & 2 \\
\hline $\begin{array}{l}\text { Available Technical Information is } \\
\text { Satisfactory }\end{array}$ & & & & & & & $x$ & $x$ & & 2 \\
\hline Main Reasons for Complaints & & & & & $x$ & $\mathrm{x}$ & & & & 2 \\
\hline Percentage of Defects & & & & & $\mathrm{x}$ & $\mathrm{x}$ & & & & 2 \\
\hline General Quality of the Product & & & & $x$ & & & & & $\mathrm{x}$ & 2 \\
\hline $\begin{array}{l}\text { Requests for Technical Information \& } \\
\text { Maintenance }\end{array}$ & & & & & $x$ & $x$ & & & & 2 \\
\hline $\begin{array}{l}\text { Planned Delivery Dates at time of } \\
\text { Placement of the Order }\end{array}$ & & & & $x$ & & & & & & 1 \\
\hline Rapid Delivery & & & & & & $x$ & & & & 1 \\
\hline Stocks near Customer & & & & & & $x$ & & & & 1 \\
\hline Products are consistently in Stock & & & & & & $x$ & & & & 1 \\
\hline Shipments rarely contain Wrong Items & & & & & & & $x$ & & & 1 \\
\hline $\begin{array}{l}\text { Shipments rarely contain Incorrect } \\
\text { Quantities }\end{array}$ & & & & & & & $x$ & & & 1 \\
\hline $\begin{array}{l}\text { Evaluation and Correction of Internal } \\
\text { Processes }\end{array}$ & & & & & & & & & $x$ & 1 \\
\hline Average Time of Delay & & & & & $\mathrm{x}$ & & & & & 1 \\
\hline Index of Delays & & & & & & & & & $x$ & 1 \\
\hline $\begin{array}{l}\text { The Supplier is advised of Possible } \\
\text { Increases } \\
\text { in Demand, Stocks are maintained }\end{array}$ & & & & & & $x$ & & & & 1 \\
\hline The Quantities Ordered are not modified & & & & & & & $x$ & & & 1 \\
\hline Delivery Frequency & & & & & $\mathrm{x}$ & & & & & 1 \\
\hline Speed of Unloading & & & & & $x$ & & & & & 1 \\
\hline $\begin{array}{l}\text { The Shipment rarely contains Replacement } \\
\text { Items }\end{array}$ & & & & & & & $x$ & & & 1 \\
\hline Written Service Policy & & $\mathrm{x}$ & & & & & & & & 1 \\
\hline Billing Procedures & $\mathbf{x}$ & & & & & & & & & 1 \\
\hline Organizational Structure & & $x$ & & & & & & & & 1 \\
\hline Product Support & & & & $x$ & & & & & & 1 \\
\hline Pricing Policy & & & & $x$ & & & & & & 1 \\
\hline Sales Conditions & & & & $x$ & & & & & & 1 \\
\hline Support of Marketing Personnel & & & & & $\mathrm{x}$ & & & & & 1 \\
\hline Correct Billing & & & & & & & $x$ & & & 1 \\
\hline Use of Customer's Packaging & & & & & & & & $x$ & & 1 \\
\hline Use of Bar Codes & & & & & & & & $\mathrm{x}$ & & 1 \\
\hline Electronic Data Transfer & & & & & & & & $x$ & & 1 \\
\hline - Monitoring of Stocks & & & & & & & & & $x$ & 1 \\
\hline Traceability & & $x$ & & & & & & & & 1 \\
\hline Swiftness in Confirming Order & & & & & $\mathrm{x}$ & & & & & 1 \\
\hline
\end{tabular}


(cont. Table 1)

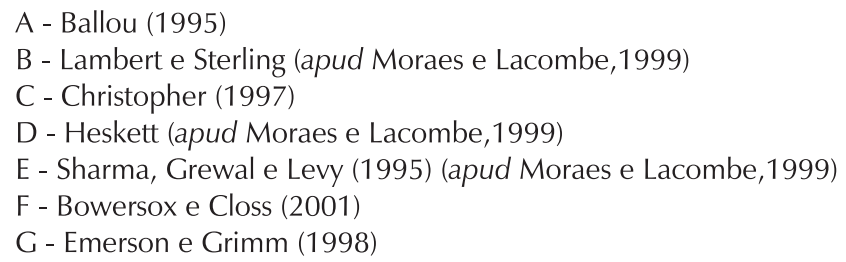

Source: Analysis of the Literature

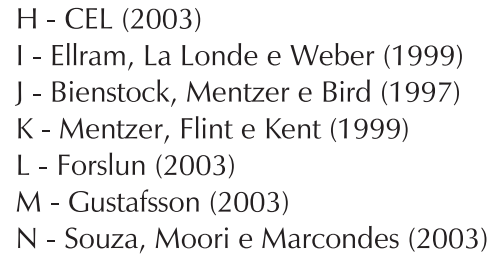

According to Gustafson (2003), different concepts have influenced the measurement and modeling of customer service but two main approaches can be identified. The first one is the physical distribution approach which holds to the concept that customer service takes place when the supply of ordered goods and delivery and information systems interface with the customers. The second approach is from marketing where the service of physical distribution is integrated with the group of customer services related to marketing. Researches in logistic services and their operationalization, by means of specific elements, have been carried out since the 1960's with Simon (1965) being the forerunner in this area. Operationalization has been carried out in two ways. The first one is according to the logistic services requirements theory, which refers to: time needed to process orders, time for producing orders, availability of stock, delivery time, limitations on the size of order, amount of consolidation permitted for shipments and consistency in satisfying the requirements mentioned here. The second method of operationalising the elements of logistic services is the use of interviews or questionnaires.

After a wide-ranging survey of the literature on logistic services, the Table 1 makes possible to visualize specific elements of logistic services and to prepare research instruments that will allow verification of the model proposed in this paper.

\section{Rating the service provided to customers}

All the researches presented in Table 1 share the position that the elements of Customer Service should be established from customer's point of view, since the value attributed to service varies according to whether it is rated by the person who provides it or by the person who receives it (CHRISTOPHER, 1999). Alcântara (2002) draws attention to this question of the customer's point of view and proposes that the qualitative evaluation of the service offered to customers is made by using the conceptual model of gaps put forward by Zeithaml et al. (1990).

\section{The conceptual model}

According to Bowersox and Closs (2001), customer service is made up of three dimensions: availability, operational performance and reliability. Some researches carried out recently by CEL (2003) in the retail sector uses nine dimensions for customer service: availability of the product; life cycle of the order; consistency of delivery dates; delivery frequency; flexibility; information systems; error correction system; support at the point of delivery and after-sales assistance. Due to the research has been made since 1994 in Brazil and considering that the sector under investigation is close to the sector which is the subject of this research, it was decided to combine the two models. Table 2 shows the relation between the dimensions from Bowersox and Closs (2001) and those from CEL (2003).

Rev. Adm. UFSM, Santa Maria, v. 1, n. 2, p. 209-224, mai./ago. 2008 
Table 2 - Dimensions of Logistic Service

\begin{tabular}{l|l}
\hline Bowersox and Closs (2001) & \multicolumn{1}{c}{ CEL (2003) } \\
\hline Availability & Availability of the product \\
\hline Operational Performance & Life Cycle of the Order \\
\hline & Consistency of Delivery Dates \\
\hline & Delivery frequency \\
\hline & Flexibility \\
\hline & Error Correction System \\
\hline Reliability & Support at the Point of delivery \\
\hline$---x----x$---- & Support Information System \\
\hline
\end{tabular}

Source: Research

From a comparison of the two models, it was noted that eight of the nine dimensions proposed by CEL (2003) fit into the three dimensions from Bowersox and Closs (2001) leaving only the 'after-sales assistance' dimension to be included in the model. The conceptual model shown in FIG. 1 was proposed on the basis of this analysis:

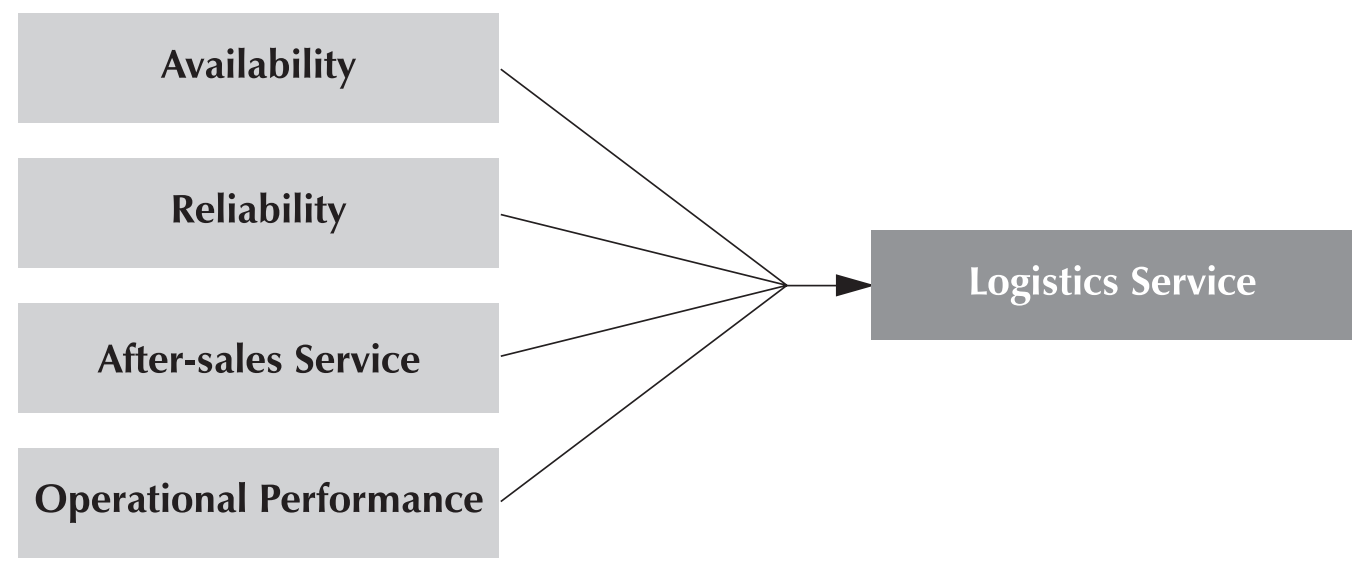

Figure 1 - Conceptual Research Model.

Source: Research

In this model, the availability dimension proposed by Bowersox and Closs (2001), corresponds to the availability of product dimension from CEL (2003). The dimensions of life cycle of the order; consistency of delivery dates; delivery frequency; flexibility; error correction system; and support at the point of delivery proposed by CEL (2003) correspond to the dimension of reliability from Bowersox and Closs (2001). The model put forward by Bowersox and Closs (2001) is made complete by the dimension of support from CEL (2003) and the final result is four dimensions for logistic service.

In spite of being based on the dimensions proposed by Bowersox and Closs (2001) and CEL (2003), the elements comprising these two models were complemented by other elements 
obtained from a survey of the literature that is shown in Table 1. The criterion for inclusion was being cited by more than one of the authors analyzed in the research and not being one of the dimensions suggested by Bowersox and Closs (2001) and CEL (2003).

The measurements of the constructs were made in a series of stages. In the first one, based on the constructs defined, the measurement items were obtained from previous research and the literature. The items making up the construct 'measurement of logistic service' were operationalised by means of items obtained initially from the models put forward by Ballou (1995), Ballou (2001), Bowersox and Closs (2001), Bienstock, Mentzer and Bird (1997), CEL(2003), Christopher (1997), Christopher (1999), Elram, Lalonde and Weber (1999), Emerson and Grimm (1998), Forslun (2003), Gustafsson (2003), Mentzer, Flint and Kent (1999), Moraes and Lacombe (1999) and Sharma, Grewal and Levy (1995) and were adapted to the needs of the present study. The scales were altered to 11 points, in order to allow treatment of the data as continuous variables and to obtain better measurement (they originally had five points).

In the second measurements development stage, a list of constructs and measurement items was submitted to a panel of specialists in logistics, composed by academics and logistic professionals who had the research topic knowledge. After this, a pre-test was carried out and analyzed in order to obtain the instrument that was used in the survey, accomplished mainly of personal interviews in order to find answers.

\section{The field research and the main sample characteristics}

The method used for data collection was the accomplishment of a survey with personal interviews. The survey method was considered to be satisfactory, since, according to Malhotra (2001), it is suitable for quantify the data and allows generalization of the results to the whole population. The unit of analysis used in this study was centered on retail customers of a pharmaceutical industry situated in the Metropolitan Region of Sao Paulo (MRSP), and the unit of observation was the owners or those responsible for purchasing in these companies. The data were collected from personal interviews during the period from 1 February 2004 to 15 March 2004. A sample of 60 (sixty) customers was used in this study.

\section{Data exploratory analysis and measurements verificaton}

\subsection{Data exploratory analysis}

At the beginning, the absent data rate was confirmed, which, according to Hair et al, (1998) is a common occurrence when questionnaires are used. These authors recommend three suitable procedures in such cases: (1) only use observations with complete data; (2) exclude the problem variable or case from the data bank; (3) use methods for interpolation of data. Hair et al. (1998) emphasize that it is up to the researcher to analyze the situation and use the procedure which he judges to be the most suitable. In this research it was decided to choose the data interpolation method based on substitution by the average figures.

The invariable and multivariable outliers were removed. The criteria for removal were those recommended by Hair et al. (1998) who mentions that the removal of invariable outliers should lead to the removal of the observations which have an average value that is three standard deviations away from the average observed in the set of data as a whole. However, the multivariate outliers were removed by using the Mahalanobis distance as the criterion. After analysis using the two processes described above, nine observations were removed, leaving 51 valid observations.

Rev. Adm. UFSM, Santa Maria, v. 1, n. 2, p. 209-224, mai./ago. 2008

$$
-218 \text { - }
$$


Given the reference to invariable normality, a few variables were found that showed themselves to be invariable abnormal. However, highly reputable authors such as Johnson and Wichern (1998), recognize the difficulty in obtaining data from the real world that correspond exactly to a normal distribution.

\subsection{Reliability and validity of the measurements}

Churchill (1995) recommends that factor analysis are used to carry out an empirical check on whether the theoretical dimensions of the construct can be confirmed or not but he warns against using mainly statistical criteria to identify dimensions without also relying on theoretical arguments. In checking validity, convergent and discriminant validity should be tested.

\subsubsection{Constructs dimensionality}

The dimensionality of the scale was examined according to two criteria. The first onewas the Barlett Sphericity Test. High values in this test, along with a significance of less than 0.05 (MORGAN and GRIEGO, 1998) indicate that there is a correlation and confirms the recommendation to use factor analysis. The second test is the Kaiser-Meyer-Okin (KMO) measure of sample adequacy. Low values of KMO indicate that the correlations between the pairs cannot be explained by other variables and, for this reason, factor analysis is not recommended. Hair et al (1998) and Malhotra (2001) recommend that a minimum value of 0.50 for the KMO test indicates that factor analysis is a suitable technique for the set of data in question.

In the specific case of this research, KMO values obtained for the three dimensions were above the limit and only the support dimension obtained a KMO value less than 0.50 (see Table 3). However, since the value was very close to the permitted limit it was decided to treat the data by using factor analysis. Another important decision was taken regarding the method of extraction and the type of rotation used in the factor analysis. The process of extraction used was Principal Axis Factoring, which, as Malhotra (2001) points out, is suitable when the main concern is to identify the existence of latent dimensions and when it is sought to obtain the smallest possible number of factors to explain the maximum amount of variance in the data, in order to use them in subsequent multivariate analysis.

Table 3 - Adequacy of the Sample

\begin{tabular}{l|c|c}
\hline & KMO & Barlett's Sphericity Test \\
\hline Support & 0.480 & 0.000 \\
\hline Reliabiility & 0.604 & 0.000 \\
\hline Performance & 0.671 & 0.000 \\
\hline Availability & 0.659 & 0.000 \\
\hline
\end{tabular}

Source: Research Data

The process of rotation used was the Varimax method which, according to Malhotra (2001), minimizes the number of variables that have high weightings on one factor, and which 
thus simplifies the interpretability of the factors. The constructs were unidimensional according to the factorial analysis.

\subsubsection{Reliability}

According to Malhotra (2001), the reliability of a scale refers to obtaining consistent results when carrying out repeated measurements. The Cronbach Alpha coefficient, which varies from 0 to 1 , is an indicator of the scale internal consistency reliability and values above 0.6 indicate that there is such reliability.

After confirming the unidimensionality of the constructs, in accordance with Hair et al. (1998), the scales reliability was assessed. This paper made use of the criterion suggested and used by Li and Calantone (1998), and according to these authors, unidimensionality can be assured as an analysis of the main components. Any construct which had a component with an eigenvalue greater than one was considered to be unidimensional.

In this analysis some of the constructs were shown do not being unidimensional. These were excluded and the factor loadings were calculated for the items of each of the dimensions proposed initially. After evaluating each of the factors making up the dimensions, Cronbach's Alpha was calculated for each of the sub-groups, as shown in Table 4.

As previously explained, when it was established that the constructs had two dimensions, the items that the researcher judged was necessary to remove were withdrawn and the premise of unidimensionality was thus ensured. 
Table 4 - Calculation of Cronbach's Alpha for each of the dimensions and their subgroups

\begin{tabular}{|c|c|c|c|c|}
\hline Dimension & Sub-group & Indicator & $\begin{array}{c}\text { Factor } \\
\text { Weighting }\end{array}$ & $\begin{array}{c}\text { Cronbach's } \\
\text { Alpha }\end{array}$ \\
\hline \multirow{4}{*}{ SUPPORT } & \multirow[t]{2}{*}{ Company Aspects } & Q21 & 0.961 & \multirow{2}{*}{0.7461} \\
\hline & & Q22 & 0.592 & \\
\hline & \multirow[t]{2}{*}{ Individual Aspects } & Q34 & 0.791 & \multirow{2}{*}{0.8779} \\
\hline & & Q35 & 0.970 & \\
\hline \multirow{11}{*}{ RELIABILITY } & \multirow{2}{*}{$\begin{array}{l}\text { Placement of } \\
\text { Orders }\end{array}$} & Q16 & 0.805 & \multirow{2}{*}{0.8576} \\
\hline & & Q17 & 0.958 & \\
\hline & \multirow{7}{*}{$\begin{array}{l}\text { Information/ } \\
\text { Delivery }\end{array}$} & Q18 & 0.731 & \multirow{7}{*}{0.8556} \\
\hline & & Q19 & 0.637 & \\
\hline & & Q20 & 0.570 & \\
\hline & & Q23 & 0.606 & \\
\hline & & Q25 & 0.782 & \\
\hline & & Q26 & 0.743 & \\
\hline & & Q27 & 0.752 & \\
\hline & \multirow[t]{2}{*}{ Control of Delivery } & Q31 & 0.621 & \multirow{2}{*}{0.6267} \\
\hline & & Q32 & 0.749 & \\
\hline \multirow{7}{*}{ PERFORMANCE } & \multirow[t]{3}{*}{ Delivery Date } & Q9 & 0.762 & \multirow{3}{*}{0.8321} \\
\hline & & Q10 & 0.612 & \\
\hline & & Q11 & 0.851 & \\
\hline & \multirow{4}{*}{$\begin{array}{c}\text { Delivery } \\
\text { Performance }\end{array}$} & Q6 & 0.897 & \multirow{4}{*}{0.7747} \\
\hline & & Q7 & 0.552 & \\
\hline & & Q13 & 0.622 & \\
\hline & & Q29 & 0.429 & \\
\hline \multirow{5}{*}{ AVAILABILITY } & \multirow{5}{*}{ Availability } & Q1 & 0.687 & \multirow{5}{*}{0.6866} \\
\hline & & Q2 & 0.673 & \\
\hline & & Q3 & 0.774 & \\
\hline & & Q4 & 0.613 & \\
\hline & & Q5 & 0.531 & \\
\hline
\end{tabular}

Source: research

\section{Research hypotheses test}

The different treatments carried out previously made it possible to confirm the hypothesis put forward in this paper: it is possible to measure the dimensions of logistic service trough reliable scales for each of them. The research resulted in the following dimensions and their corresponding elements (Table 5): 
Table 5 - Dimensions (Factors) of the model

\begin{tabular}{ll} 
Support Dimension \\
\hline Sub-group 1
\end{tabular}

21 The friendliness of employees when dealing with customer is satisfactory

22 The company's service staff are well trained to deal with customers

\begin{tabular}{l} 
Sub-group 2 \\
34 The response to requests for technical information from my shop are dealt with in a satisfactory manner \\
\hline 35 The time the company takes to respond to requests for technical information is satisfactory \\
Reliability Dimension \\
Sub-group 1
\end{tabular}

16 The form and the process which I use to place orders fully meets my requirements

17 It is easy to order from the company

\begin{tabular}{l} 
Sub-group 2 \\
18 Whenever an order is placed, the company gives me information about how it will be dealt with \\
\hline 19 The information provided by the company's employees is reliable \\
\hline 20 The company allows me to follow up the orders placed in an efficient manner \\
23 The time taken by the company to advise about changes to the orders is satisfactory \\
25 The company's employees whom I deal with when delivery is made are helpful \\
\hline 26 The friendliness of service at the time of delivery is excellent \\
\hline 27 The punctuality of deliveries is completely satisfactory \\
Sub-group 3
\end{tabular}

31 The deliveries rarely contain changed items

32 The company shows that it is in control of its delivery operations

$$
\text { Performance Dimension }
$$

\section{Sub-group 1}

9 The requests for deliveries to be made before the specified date are fully satisfied

10 I am completely satisfied with the frequency of deliveries

$11 \mathrm{I}$ am completely satisfied with special deliveries, such as emergencies and those made before the specified date and time.

\section{Sub-group 2}

6 The time between placing the order and receiving the product fully meets my needs

7 The number of deliveries made on time is completely satisfactory

13 Complaints about damage, mistakes in documents and delays are settled in a satisfactory manner

29 When delivery is made. the products are unloaded in an orderly manner

$$
\text { Availability Dimension }
$$

1 Whenever I place an order the products requested are delivered in the exact quantities ordered

2 Whenever I place an order, the products are always available to provide rapid service

3 The percentage of products ordered which have problems is very small

4 The number of deliveries that have problems is large

5 I am fully satisfied with the time taken to deliver oders with problems

Source: Research. 


\section{Implications of the research}

In this piece of research, the field of study of logistics management, which is still under development, came up against the challenge of carrying out studies of the type that link specific areas of an organization, such as marketing and logistics, via customer service. It is necessary to try to define and survey the whole field of logistic customer service management, since this area produces profits. Its relation to strategic decision-making, whether it is in sales or marketing on a wider scale is becoming increasingly clear and suggest that more studies should be carried out into this topic.

The conclusions from this research should be taken as a basis for further scientific development of the topic and, in exactly the same way, as the basis for further development of the business processes of the company where the research was carried out, in relation to its retail customers in the Metropolitan Region of São Paulo. Since the results relate to the company where the research was carried out, they should not be generalized to other customers in the rest of the country and it is necessary to expand the research to these other regions in order to obtain generic answers. In addition to these considerations, it is important to note that the results presented here cannot be generalized to companies that do not belong to the pharmaceutical industry.

\section{References}

ALCÂNTARA, R. L. C. A integração das estratégias de logística e marketing maximizando o serviço ao cliente: algumas reflexões. Available at Internet: <http://www. gepai.dep.ufscar.br/publicacoes.htm>, 18 Sept. 2002.

BALLOU, R. H. Logística empresarial. São Paulo: Atlas, 1995.

BALLOU, R. H. Gerenciamento da cadeia de suprimentos. São Paulo: Bookman, 2001.

BIENSTOCK, C. C.; MENTZER, J. T.; BIRD, M.M. Measuring physical distribution service quality. Journal of the Academy of Marketing Science, 1997.

BOWERSOX, D. J.; CLOSS, D. J. Logística empresarial. São Paulo: Atlas, 2001.

CEL. Pesquisa de Benchmark: serviço ao cliente. 2003. Available at internet: <http://www.cel. coppead.ufrj.br>, 26 Feb. 2005.
CHRISTOPHER, M. Logística e gerenciamento da cadeia de suprimentos. São Paulo: Pioneira, 1997.

CHRISTOPHER, M. O marketing da logística. São Paulo: Futura, 1999.

DANTAS, E. M. A. Estágio da organização logística em três empresas do setor de bebidas: um estudo de caso. Rio de Janeiro: UFRJ/COPPEAD, 2000.

DAUGHERTY, P.J., SABATH, R.E., ROGERS,

D.S. Competitive Advantage through customer responsiveness. The Logistics and Transportation Review, v.28, n.3, p. 0-2 1992.

ELLRAM, L. M.; LA LONDE, B. J.; WEBER, M. M. Retail logistics International. Journal of Physical Distribution and Logistics Management, Bradford, v. 29, n. 7/8, p. 477, 1999.

EMERSON, C. J.; GRIMM C. M. The relative importance of logistics and marketing-customer service. Journal of Business Logistics, v.19, n.1, p. 17-32 1998. 
FAWCETT, S. E.; CLINTON, S. R. Enhancing Logistics Performance to improve the competitiveness of manufacturing organizations. Production and Inventory Management Journal, p.40-66, Jan./Mar. 1996.

FLEURY, P. F.; WANKE, P.; FIGUEIREDO, K. F. Logística empresarial. São Paulo: Atlas, 2000.

FLEURY, P.F.; LAVALLE, C.R. Avaliação do serviço de distribuição física. Gestão e Produção, v. 4, n. 2, p. 174-185 1997.

GUSTAFSSON, A. Retail' requirements on logistic service. In: EurOMA and POMS joint international Conference, 2003.

HESKETT, J. Controlling customer logistics service. International Journal of Physical Distribution, v. 1, n. 3, p.140-145, 1971.

KOTLER, P. Administração de marketing. São Paulo: Atlas, 2000.

LAMBERT, D. M.; STOCK, J.R.; VANTINE, J.G. Administração estratégica da logística. São Paulo: Vantine, 1998.

MALHOTRA, N. Pesquisa de marketing: uma orientação aplicada. 3. ed. Porto Alegre: Bookman, 2001.

MENTZER, J.; GOMES; KRAPFEL Jr., R. E. Physical distribution service: a fundamental market concept? Journal of the Academy of Market Science, p.55, Winter 1989.
MORAES, M. N.; LACOMBE, A. Medição de qualidade em serviços de distribuição: um estudo de caso. In: ENANPAD, ANNUAL CONFERENCE, $23^{\text {th }}$, 1999, Foz do Iguaçu Proceedings ... Anpad; Rio de Janeiro: Enanpad.

RITTER, J. G. S. F.; MARCHETTI, R. Z.; PRADO, P. H. 2002. Busca de informações em compras industriais complexas. In: ENANPAD, ANNUAL CONFERENCE, 23 ${ }^{\text {th }}, 1999$, Foz do Iguaçu Proceedings ... Anpad: Rio de janeiro.

ROSENBLOOM, B. Canais de marketing. São Paulo: Atlas, 2002.

SIMCHI-LEVI, D.; KAMINSKY, P.; SIMCHI-LEVI, Edith. Cadeia de suprimentos, projeto e gestão. Porto Alegre: Bookman, 2003.

SHARMA, A.; GREWAL, D.; LEVY, M. The breakthrough thinking in logistics. Journal of Business Logistics, v. 16, n. 2, p. 1-22, 1995.

SOUZA, M. F. S.; MOORI R. G.; MARCONDES, R. C. Sincronização das expectativas dos clientes com a prática dos fornecedores quanto a custos, confiabilidade e qualidade In: ENANPAD, ANNUAL CONFERENCE, 23 ${ }^{\text {th }}$, 1999, Foz do Iguaçu Proceedings ... Anpad: Rio de janeiro Enanpad. ZEITHMAL, V. A.; PARASURAMAN, A.; BERRY, L. L. Delivering quality service. New York: The Free Press, 1990. 